\title{
THE BIOCHEMICAL BASIS FOR THE SYMBIOSIS BETWEEN THE ANT, ATTA COLOMBICA TONSIPES, AND ITS FOOD FUNGUS
}

\author{
MICHAEL M. MARTIN and JOAN STADLER MARTIN \\ The Department of Chemistry, The University of Michigan, Ann Arbor, \\ Michigan 48104
}

(Received 8 fuly 1969)

\begin{abstract}
The fungus cultured by the attine ant, Atta colombica tonsipes, is deficient in the full complement of proteolytic enzymes necessary to grow well on substrates in which the nitrogen is present predominantly as protein. The faecal material of the ant, which is regularly applied to the fungus gardens of the ant, contains allantoic acid, allantoin, ammonia, and a mixture of twenty one amino acids. In addition, it exhibits significant protease activity. The application of faecal material to the fungus cultures, therefore, directly compensates for the metabolic deficiencies of the fungus. Many other features of the ants' fungus-culturing behaviour can be interpreted in terms of their effect upon the competitive status of the fungus. The symbiotic association of $A$. c. tonsipes and its food fungus is a biochemical alliance predicated upon metabolic integration. The ants directly contribute their protein-degrading capabilities to the fungus, and the fungus indirectly contributes its cellulose-degrading ability to the ants.
\end{abstract}

\section{INTRODUCTION}

T'HE ATTINE ants culture a fungus in their nests and exploit this fungus as their primary and probably sole food source (BELT, 1874; MÜLLER, 1874; WHEELER, 1907; WeBER, 1958, 1966). The fungus or group of fungi grown by the attines is believed to be peculiar to attine nests. The attine ant-fungus association is an obligate symbiosis for both organisms. If the ants are removed from agar-based laboratory cultures of their fungus a rapid deterioration of the culture ensues, and other microorganisms replace the ants' fungus (MOELLER, 1893; WEBER, 1956a, b, 1958). The mechanism by which the attines maintain flourishing cultures of a fungus which cannot survive in nature independent of them has been the subject of much speculation. One intriguing theory (WEBER, 1947, 1966) was that the ants' salivary and anal secretions, which are regularly applied to the fungus gardens, contain antibiotic substances which prevent the growth of alien fungi. Unfortunately, recent studies (MARTIN et al., 1969) have failed to confirm this appealing explanation. Nonetheless, the behaviour of the ants (HUBER, 1905; WEBER, 1947, 1956a, 1958, 1966) does strongly suggest a crucial rôle for these secretions. Fresh leaves and flowers cut from live plants serve as substrate in the fungus gardens of the two most highly evolved attine genera, Acromyrmex and Atta. A leaf fragment 
brought into the nest for incorporation into a fungus garden is first cleaned and scraped. It is then cut into very small pieces becoming quite pulpy and moist, presumably from juices expressed from the leaf and saliva applied by the ant. A feacal droplet is deposited on the leaf particle, which is then inserted into the matrix of the garden, and several tufts of mycelium are planted on it. The newly incorporated leaf particle may receive several additional faecal applications from other ants. As WEBER $(1947,1958,1966)$ has repeatedly emphasized, substances present in the salivary and anal secretions very probably serve to create environmental conditions favourable to the growth of the food fungus.

'This paper is a study of the metabolic characteristics of the fungus cultured by Atta colombica tonsipes, and the chemical composition of the ants' faecal material. The results of these studies have clarified the significance of the ants' faecal applications, and have permitted the symbiosis to be understood in biochemical terms.

\section{MATERIALS AND METHODS}

The ant, Atta colombica tonsipes Santschi

Live ants were the source of all materials described in this paper. Our colony, containing a queen collected in May 1967, near Summit, Canal Zone, was maintained at 25 to $30^{\circ} \mathrm{C}$ and 80 to 90 per cent r.h. The colony was provided with lilac leaves (Syringa vulgaris) for use as substrate for its fungus cultures. BORGMEIER (1959) considers Atta colombica tonsipes Santschi to be a synonym for Atta colombica Guér. but WeBER (1968) does not. The ants utilized in this study were identified by Professor Weber, and his determination is used throughout the paper.

\section{Growth studies on the fungus}

Pure cultures of the fungus grown in the nest of A. c. tonsipes werc obtained by standard isolation techniques starting from the fungus gardens of the captive colony. The synthetic medium in which the growth studies were conducted has been described elsewhere (MARTIN and WEBER, 1969). Solid cultures contained $2 \%$ agar. Casein hydrolysate (enzymatic), lactalbumin hydrolysate (enzymatic), Peptone T, Bacteriopeptone, casein (Hammerstein), lactalbumin, and zcin (all from Nutritional Biochemicals Corp., Cleveland, Ohio) were employed as nitrogen sources. Liquid cultures were inoculated with $0.1 \mathrm{ml}$ of an homogenate of a pure seed culture and were shaken at $250 \mathrm{rev} / \mathrm{min}$ at $25^{\circ} \mathrm{C}$. Agar cultures were inoculated with a mycelial fragment (approximately $1 \mathrm{~mm}^{2}$ in area) from a pure seed culture and werc kept at $25^{\circ} \mathrm{C}$. The extent of growth in liquid cultures was determined by filtering the mycelium, drying the filtered mycleium for $6 \mathrm{hr}$ at $60^{\circ} \mathrm{C}$, and weighing. The area covered by the fungus was determined as a measure of the extent of growth on agar plates.

Analysis of rectal contents

Gasters of live worker ants, ranging in length from 3 to $7 \mathrm{~mm}$, were dissected under distilled water to free the swollen rectum. The rectum varied in volume 
from 0.1 to $0.5 \mu \mathrm{l}$, averaging $0.3 \mu \mathrm{l}$. The contents were removed with a very fine glass needle attached to a syringe. Pooled rectal contents were kept on ice until analysed. The external dimensions of the rectum were determined using an ocular micrometer. The volume was determined assuming a cylindrical geometry for the rectum.

Allantoin and allantoic acid were identified in the rectal fluid by paper chromatography using Whatman No. 1 chromatography paper and a solvent system composed of butanol-ethanol-water $(4: 1: 1, \mathrm{v} / \mathrm{v} / \mathrm{v})$. They were visualized with a spray of $1 \%$ dimethylaminobenzaldehyde in $2 \%$ alcoholic hydrochloric acid (Marini-Betollo and Trabacchi, 1956). The same paper chromatographic system was used to establish that urea, creatine, and creatinine were not present in the rectal fluid. For visualization of urea, $1 \%$ dimethylaminobenzaldehyde in $2 \%$ alcoholic hydrochloric acid spray was used. For visualization of creatine and creatinine, alkaline picric acid (BLOCK et al., 1958) and sodium nitroprusside (HoFmann and WüNSCH, 1958) sprays were utilized. The absence of uric acid was also established by a paper chromatographic procedure using $5 \%$ monobasic sodium phosphate-isoamyl alcohol $(3: 2, \mathrm{v} / \mathrm{v}$ ) (CARTER, 1950) as a developing solvent. Visualization was effected by spraying with borate buffer followed by Gibb's reagent and finally $1 \%$ silver nitrate (KaLA et al., 1959). The lower limits of detection for these four substances were as follows: urea $(0.05 \mu \mathrm{g} / \mathrm{ant})$, uric acid $(0.05 \mu \mathrm{g} /$ ant $)$, creatine $(0.05 \mu \mathrm{g} / \mathrm{ant})$, and creatinine $(0.02 \mu \mathrm{g} / \mathrm{ant})$. Allantoin and allantoic acid were determined quantitatively by the procedure of CHRISTMAN et al. (1944). Absorbance was measured at $520 \mathrm{~m} \mu$ in a Coleman Jr. spectrophotometer. Standards were run with every determination.

Ammonia was isolated by the Conway (1963) microdiffusion procedure, using a modified Obrink apparatus (Scientific Products, Evanston, Illinois), and was determined by the phenol-hypochlorite reaction (Russell, 1944).

A complete amino acid analysis was carried out on a pooled sample of rectal fluid derived from 305 ants, using standard ion-exchange chromatographic procedures. The analysis was conducted by Dr. Thomas Hernandez, Department of Pharmacology, and Dr. Robert Coulson, Department of Biochemistry, School of Medicine, Louisiana State University, New Orleans. Cysteine and tryptophan were determined by gas-liquid chromatography (GEHRKE and STALLING, 1967).

\section{Proteolytic enzyme activity}

Proteolytic enzyme activity was measured in $0.05 \mathrm{M}$ phosphate buffer at $37^{\circ} \mathrm{C}$ and $\mathrm{pH}$ 's of $5 \cdot 8,6 \cdot 0,6 \cdot 5$, and $7 \cdot 3$, using the Azocoll procedure (Calibiochem, Los Angeles, California). Absorbance was read on a Coleman Jr. spectrophotometer at $580 \mathrm{~m} \mu$. Distilled water controls were run. Maxillary, mandibular, postpharyngeal, and salivary glands, rectal contents, crop contents, midgut tissue, and midgut tissue plus contents were obtained by dissection in triply distilled, deionized water, buffered at the same $\mathrm{pH}$ as the assay, and were kept on ice until assayed. All tissues were homogenized by hand. In addition, particles of cornflakes (Kellogg Co., Battle Creek, Michigan) which had been prepared and treated by the 
ants for incorporation into their fungus gardens were recovered from the ants' nest. The cornflake particles were examined microscopically, and those few mycelial strands adhering to them were removed. After homogenization, they were centrifuged at $5^{\circ} \mathrm{C}$, and the supernatant was assayed for protease activity. No attempt was made in any of these assays to activate inactive proteases which may have been present.

\section{RESULTS}

Some metabolic characteristics of the fungus cultured by A. c. tonsipes

In experinents preliminary to the work described in this paper, it was observed that the growth of the fungus cultured by $A$. $c$. tonsipes in Sabouraud's dextrose broth (Difco) was greatly enhanced by supplementing the culture medium with amino acid mixtures. The nitrogen source in Sabouraud's dextrose broth is Neopeptone (Difco), and enzymatic digest composed largely of peptones, fairly high molecular weight soluble polypeptides. The addition of protein to the culture had no growth-enhancing effect. This observation suggested that when the fungus is cultured in Sabouraud's dextrose broth, the growth-limiting factor is a $\alpha$-amino nitrogen, or more likely some specific amino acid or amino acids. Since the nitrogen source in the culture medium contains what should be an ample supply of all of the amino acids in polypeptide form, these findings suggest that the fungus might be deficient in the enzymatic apparatus necessary for efficient utilization of polypeptides. To test this possibility we have studied the growth of the food fungus of A. c. tonsipes in defined synthetic media on different nitrogen sources. We have utilized two enzymatic hydrolysates of the same protein, casein, which differ in the extent of hydrolysis of the polypeptide structure. Since the hydrolysates are derived from the same protein, they will have the same relative total amino acid compositions. Peptone T (Nutritional Biochemicals Corp.) is a tryptic digest of casein, composed largely of peptones and containing a relatively small complement of low molecular weight peptides and free amino acids. By contrast in Casein Hydrolyzate-Enzymatic (Nutritional Biochemicals Corp.), the hydrolysis of the casein has proceeded to a much greater extent, and the final hydrolysate consists primarily of free amino acids and low molecular weight peptides. The growth of the food fungus of $A$. c. tonsipes on these two nitrogen sources is summarized in Table 1.

Both shaken liquid cultures and solid agar cultures of the fungus grew significantly better on enzymatic casein hydrolysate than on Peptone $T$. In the liquid cultures after a 7-day incubation period the amount of growth was six- to eightfold greater in the cultures containing the enzymatic casein hydrolysate than in the ones containing Peptone $\mathrm{T}$. On the solid agar cultures after a 21-day incubation period the area covered by the fungus was three- to fivefold greater in the cultures containing the enzymatic casein hydrolysate. In addition, the fungus grew very poorly in a shaken liquid culture when the nitrogen source was precipitated casein. In other experiments it was found that the fungus grew well on enzymatic lactalbumin hydrolysate, and very poorly on Bacteriopeptone, lactalbumin, or zein. 
From these experiments we conclude that the fungus cultured by $A$. c. tonsipes lacks the full complement of proteolytic enzymes necessary to make efficient use of polypeptide nitrogen. This metabolic limitation is obviously of great ecological significance, since it means that the fungus will be at a considerable competitive

TABle $1-$ The growth of $A$. $c$. tonsipes FOOD FUNGUS IN DEFINED Media CONTAINING EITHER AN ENZYMATIC CASEIN HYDROLYSATE RICH IN FREE AMINO ACIDS OR A CASEIN PEPTONE POOR IN FREE AMINO ACIDS

A. Shaken liquid cultures $\left(25^{\circ} \mathrm{C}, 250 \mathrm{rev} / \mathrm{min}, 7\right.$-day growth period)

\begin{tabular}{lclr} 
Nitrogen source & $\begin{array}{c}\text { Conc. } \\
(\mathrm{mg} / \mathrm{ml})\end{array}$ & \multicolumn{1}{c}{ Dry wt. fungus (mg) } & $\begin{array}{c}\text { Mean } \\
\text { wt. (mg) }\end{array}$ \\
\hline Casein hydrolysate & $1 \cdot 0$ & $29,32,41,41,45,54,58,73$ & 47 \\
Peptone T & $1 \cdot 0$ & $3,6,7,7,9$ & 8 \\
Casein hydrolysate & $2 \cdot 0$ & $45,67,78,88,92,110,124,126$ & 91 \\
Peptone T & $2 \cdot 0$ & $3,7,7,31$ & 12 \\
Casein hydrolysate & $4 \cdot 0$ & $60,62,66,104,139,148,150,153$ & 110 \\
Peptone T & $4 \cdot 0$ & $0,4,18,20,34,36$ & 19 \\
\hline
\end{tabular}

B. Solid agar cultures $\left(25^{\circ} \mathrm{C}, 21\right.$-day growth period)

Conc.

\begin{tabular}{lclc} 
Nitrogen source & $(\mathrm{mg} / \mathrm{ml})$ & \multicolumn{1}{c}{ Area of fungus $\left(\mathrm{mm}^{2}\right)$} & Area $\left(\mathrm{mm}^{2}\right)$ \\
\hline Casein hydrolysate & $1 \cdot 0$ & $32,32,36,49,51,61$ & 44 \\
Peptone T & $1 \cdot 0$ & $8,12,16,18,18,21,26$ & 17 \\
Casein hydrolysate & $2 \cdot 0$ & $52,54,57,64,65,100$ & 65 \\
Peptone T & $2 \cdot 0$ & $10,13,14,14,16,16,18$ & 14 \\
\hline
\end{tabular}

disadvantage when required to live on a substrate in which the nitrogen is present predominantly as polypeptide. In this regard, fresh leaf material would seem to be a most inappropriate substrate for this fungus, since most of the amino acid nitrogen in leaves is present as protein. The ability of the ants to grow their fungus on such an unlikely substrate testifies to the efficacy of their fungus-culturing activities in compensating for the critical metabolic deficiencies of their fungus.

\section{The composition of the ants' faecal material}

Since the form of nitrogen available to the fungus greatly affects its growth, and since faecal material is added to the natural fungus gardens, we determined the nitrogenous components of the ants' faecal material (Table 2). In addition to allantoic acid and allantoin, the two major nitrogenous excretory products, there are significant quantities of ammonia and free amino acids present. No urea, uric acid, creatine, or creatinine could be detected. All twenty-one of the common natural amino acids are present in the rectal fluid (Table 3). The six amino acids glutamic acid, histidine, arginine, proline, lysine, and leucine make up $82 \cdot 1$ per cent (by weight) of the total. 
The actual values reported in Tables 2 and 3 should be regarded as minimum values, since the removal of the fluid from the ants' rectum was rarely quantitative and sometimes resulted in the loss of as much as a third of the material. Nonetheless, it is evident that when the ants defaecate on their fungus gardens they are supplementing the culture medium with nitrogenous substances which would be very beneficial to the growth of their fungus.

TABle 2-Nitrogenous components of the rectal fluid of $A$. $c$. tonsipes

\begin{tabular}{lcc}
\hline \multicolumn{1}{c}{ Substance } & $\begin{array}{c}\text { Range } \\
(\mu \mathrm{g} / \text { ant })\end{array}$ & $\begin{array}{c}\text { Average value } \\
(\mu \mathrm{g} / \text { ant })\end{array}$ \\
\hline Allantoic acid & $1 \cdot 4-2 \cdot 5$ & 1.9 \\
Allantoin & $0.7-2 \cdot 0$ & $1 \cdot 3$ \\
Free amino acids & - & 0.46 \\
Amnonia & $0.07-0.14$ & 0.10 \\
\hline
\end{tabular}

Table 3-FreE amino acids of the ReCtal fluid of $A$. c. tonsipes

\begin{tabular}{|c|c|c|}
\hline Amino acid & $\mu$ moles/ant & $\mu \mathrm{g} / \mathrm{ant}$ \\
\hline Glutamic acid & $6.34 \pm 0.25 \times 10^{-4}$ & $83.7 \times 10^{-3}$ \\
\hline Histidine & $4 \cdot 69 \pm 0 \cdot 14$ & $73 \cdot 2$ \\
\hline Arginine & $4 \cdot 11 \pm 0 \cdot 33$ & $71 \cdot 5$ \\
\hline Proline & $4 \cdot 00 \pm 0 \cdot 20$ & $46 \cdot 0$ \\
\hline Lycine & $2 \cdot 03 \pm 0.12$ & $29 \cdot 6$ \\
\hline Leucine & $1.97 \pm 0.08$ & $25 \cdot 8$ \\
\hline Valine & $1 \cdot 26 \pm 0 \cdot 15$ & $14 \cdot 7$ \\
\hline Aspartic acid & $1 \cdot 20 \pm 0 \cdot 12$ & $16 \cdot 0$ \\
\hline Glutamine & $1 \cdot 14 \pm 0 \cdot 10$ & $14 \cdot 9$ \\
\hline Glycine & $1 \cdot 11 \pm 0 \cdot 12$ & $8 \cdot 3$ \\
\hline Phenylalanine & $1 \cdot 09 \pm 0 \cdot 10$ & $18 \cdot 0$ \\
\hline Serine & $1.09 \pm 0.13$ & $14 \cdot 4$ \\
\hline Alanine & $0.91 \pm 0.07$ & $8 \cdot 1$ \\
\hline Isoleucine & $0.60 \pm 0.05$ & 7.9 \\
\hline 'Tyrosine & $0.46 \pm 0.05$ & $8 \cdot 3$ \\
\hline Threonine & $0.42 \pm 0.06$ & $5 \cdot 0$ \\
\hline Cystine & $0.37 \pm 0.06$ & 8.9 \\
\hline Ornithine & $0.24 \pm 0.04$ & $3 \cdot 2$ \\
\hline Methionine & $0.20 \pm 0.02$ & $2 \cdot 9$ \\
\hline Cysteine & $0.14 \pm 0.10$ & 1.7 \\
\hline Tryptophan & $0.11 \pm 0.08$ & $2 \cdot 2$ \\
\hline
\end{tabular}

The presence of proteolytic enzymes in the rectal fuid

Any beneficial effect on the growth of the ant's fungus resulting from the nitrogenous nutrients added to the garden in the faecal fluid will necessarily be short-lived. As soon as these substances are consumed, the competitive position of 
the fungus will again be very poor, since it will still be faced with the problem of sustaining itself on a growth medium in which the nitrogen is largely in the form of protein. What the fungus culture most needs is a supplemental supply of proteolytic enzymes. We, therefore, examined the possibility that either the saliva or the faecal material contained proteolytic enzymes.

No protease activity could be detected in homogenates of the salivary glands, mandibular glands, maxillary glands, or postpharyngeal glands, all of which might be regarded as reasonable sources of a secretion applied to the leaf particles during their preparation for incorporation into the garden. However, significant protease activity was observed in the midgut and the contents of the rectum (Table 4). The rectal fluid contained from two and a half to five times the activity of the midgut contents. Thus it appeared that the faecal material might also be a source of supplemental proteolytic enzymes for the fungus.

Table 4-Proteolytic enzyme activity at pH 6.5 Of glands, tissues, and fluids DERIVED FROM $A$. $c$. tonsipes

\begin{tabular}{ll}
\hline \multicolumn{1}{c}{ Material } & Activity \\
\hline Salivary gland $(10)^{*}$ & $\mathrm{Nil} \dagger$ \\
Maxillary gland $(10)$ & $\mathrm{Nil}$ \\
Mandibular gland $(6 \cdot 5)$ & $\mathrm{Nil}$ \\
Postpharyngeal gland $(10)$ & $\mathrm{Nil}$ \\
Crop contents $(10)$ & $\mathrm{Nil}$ \\
Midgut tissue $(10)$ & $\mathrm{Nil}$ \\
Midgut tissue + contents $(6-10)$ & $110-120 \mathrm{ng} /$ ant + \\
Rectal contents $(5-8)$ & $300-480 \mathrm{ng} /$ ant + \\
\hline
\end{tabular}

* Figures in parentheses $=$ number of worker ants from which samples were pooled for assay.

$\dagger$ Nil activity also observed at pH 5.8 and $7 \cdot 3$.

$\ddagger$ Expressed in terms of the number of ng of fungal protease (Sigma, Type VI) which exhibited comparable activity in the Azocoll assay; comparable activity also observed at $\mathrm{pH} 5 \cdot 8,6 \cdot 0$, and $7 \cdot 3$.

In order to ascertain whether the ants actually were excreting active proteolytic enzymes on to their fungus cultures, a substrate which had no proteolytic activity of its own was recovered from the ants after it had been prepared by them for incorporation into a garden. In captivity $A$. $c$. tonsipes rcadily utilizes cornflakes as a substrate for their fungus cultures, treating them, by all appearances, exactly like leaves. Untreated cornflakes had no protease activity. Pieces of cornflakes, recovered from a fungus garden just after the ants had completed the entire preparation procedure, were soft, moist, and tacky. Homogenates of treated cornflake particles had significant protease activity. Thus we have demonstrated that the ants' faecal material provides the fungus with both a nutrient supplement and a proteolytic enzyme supplement. 


\section{DISCUSSION}

The significance of the application of faecal material to the fungus gardens

The fungus cultured by $A$. $c$. tonsipes cannot grow well on a substrate in which the nitrogen is present primarily as protein, because it apparently lacks the requisite complement of enzymes necessary to degrade substrate proteins efficiently. The application of faecal material to the substrate and the fungus gardens compensates for this crucial metabolic deficiency, and is a major contributing factor in the ants' ability to grow their fungus on a substrate which would otherwise be entirely unsuitable. The protease in the faecal material compensates directly for a deficiency in the fungus. In addition, the short-term needs of the newly planted fungus are filled by the mixture of amino acids present in the faecal fluid. Ammonia is also present, thereby permitting the fungus to utilize the amino acids as such or as metabolic precursers for other substances rather than squandering them simply for their amino nitrogen content.

Presumably allantoin and allantoic acid can also serve as sources of amino nitrogen, but it seems likely that these components are also serving an additional, more critical function. Allantoin has the property of dispersing protein (LESSER, 1938; Lubowe and Mecca, 1959). The dispersal of a protein renders it more susceptible to hydrolytic breakdown. Hence, the degradation of substrate protein would be facilitated by the dispersing action of the allantoin in the faecal material. It is interesting to note in this regard that allantoin is the major nitrogenous excretory product of blowfly larvae, the only other insect which has been reported to excrete proteolytic enzymes (HOBSON, 1931a, b; WATERHOUSE and IRZYKIEWEICZ, 1957). In this case also, the protein-degrading properties of the excrement are important to the insect. The excreta serve an extra-intestinal digestive function in that they liquefy the medium in which the maggots are living, thereby providing a liquid food for them to ingest. It is of interest to note in passing that the efficacy of maggot therapy stems in part from the proteindispersing, protein-hydrolysing properties of the excreta, which accelerate the softening and ultimate removal of horny necrotic tissue.

The symbiosis between $A$. c. tonsipes and its food fungus can be described in biochemical terms. It is a biochemical alliance predicated on metabolic integration. The ant contributes the ability to degrade protein to the fungus, making it possible for the fungus to exploit a substrate from which it would otherwise be excluded by other micro-organisms better able to utilize the nutrients present in it. The ants in return receive the use of the cellulose-degrading ability of the fungus (MARTIN and WEBER, 1969). In so doing the ants gain access to the vast cellulosic reserves of the rain forest for use as a carbon source. The pre-eminent success of Atta in the New World Tropics testifies to the ecological soundness of a leaf-cutting fungus-growing strategy.

The effect of the ants' activities on the competitive status of the fungus

The outcome of interspecific microbial competition is largely determined by the relative growth rates of the competing organisms (Brock, 1966; PARK, 1968). 
GARRETT $(1950,1956)$ has identified five factors which contribute to a high degree of competitive ability in a fungus. These are (1) a high inoculum potential, permitting the fungus to overcome substratum resistance readily, (2) rapid hyphal growth, favouring rapid and extensive colonization and coverage of the substratum, (3) good enzyme production, favouring rapid nutrient utilization, (4) antibiotic production, reducing competition, and (5) tolerance to antibiotics produced by other organisms. It is instructive to examine the entire repertoire of fungusculturing activities of the ants in the context of their effect on the competitive status of their food fungus.

The process of scraping the leaves to remove the waxy coating and the maceration of the leaf particle which follows will break down the leaf's barriers to fungal infection, and will effectively serve to increase the inoculum potential of the fungus. The maceration of the leaf also results in the liberation of the contents of the leaf tissue, thereby permitting immediate exploitation by the fungus as soon as it is planted. The rapid colonization and coverage of the substratum is aided by the ants' habit of planting several tufts of mycelium directly on it. Any contaminant arriving at this point will already find itself in second place, competing on a substratum already extensively colonized by the ants' fungus. The nutrient supplement provided in the faecal material will accelerate the initial phases of growth. The protease present in the faecal material and also leaf enzymes liberated from cellular compartments during the maceration of the leaf supplement the enzymes produced by the fungus, and serve to facilitate the utilization of substrate nutrients.

Thus, not only can the significance of the application of faecal material to the fungus gardens be understood in terms of well-established biochemical and ecological principles, but so can most of the other activities directly related to maintenance of the fungus cultures. The net effect of all of these activities is to enhance the competitive ability of the fungus to such a level that in the narrow niche described by the ants' fungus chamber it emerges as the dominant microorganism which excludes all competitors.

\section{The implication of enzyme excretion}

In general, it would seem to be a very wasteful expenditure of valuable metabolic energy for an organism to synthesize digestive enzymes only to excrete them. Presumably such a practice would be advantageous to an organism only under certain rather special circumstances, such as in a symbiotic association in which the symbiont made use of the enzyme, or where the excreted enzyme served some extra-intestinal digestive function. It is not known just how widespread is the practice of excreting digestive enzymes. Perhaps it is necessary for insects to produce such large quantities of digestive enzymes that some survive passage through the alimentary canal, simply to guarantee adequate digestion of ingested nutrients. In other words, perhaps the excretion of digestive enzymes is a necessary extravagance of many insects, which a few, such as the blowfly and the attines, have succeeded in turning to their advantage. Or perhaps it is a practice peculiar to only a few restricted groups, and perhaps this characteristic played a key rôle in 
the evolution of the fungus-growing ants. Further studies on the enzymatic composition of insect excreta will be required in order to establish the generality of this practice and to define its significance.

Acknowledgements-We wish to thank the National Institutes of Health for a grant (AI-07386) which supported most of this work. We wish to acknowledge our indebtedness to Professor NeAL WeBer of Swarthmore College for his interest, encouragement, and advice in the early phases of this work, which greatly facilitated the initiation of this study. Finally, we wish to express our appreciation to Mr. JeFFreY T. MARTIN for delaying his arrival into this world by 2 weeks, thereby permitting the junior author to complete her phase of the work.

\section{REFERENCES}

BELT T. (1874) The Naturalist in Nicaragua. John Murray, London.

Block R. J., Durrum E. L., and Zweig G. (1958) Paper Chromatography and Paper Electrophoresis, 2nd ed., p. 3481. Academic Press, New York.

Borgmeier T. (1959) Revision der Gattung Atta Fabricus (Hymentoptera, Formicidae). Studia ent. 2, 321-390.

Brock T. D. (1966) Principles of Microbial Ecology, pp. 114-180. Prentice-Hall, Englewood Cliffs.

CARTER C. E. (1950) Paper chromatography of purine and pyrimidine derivatives of yeast ribonucleic acid. F. Am. chem. Soc. 72, 1466-1471.

Christman A. A., Foster P. W., and Esterer M. B. (1944) The allantoin content of blood. F. biol. Chem. 155, 161-171.

Conway E. J. (1963) Microdiffusion Analysis and Volumetric Error. Chemical Publishing Co., New York.

GarretT S. D. (1950) Ecology of the root-inhabiting fungi. Biol. Rev. 25, 220-234.

GarretT S. D. (1956) Biology of Root Infecting Fungi. Cambridge University Press, London.

GehrKe C. W. and Stalling D. L. (1967) Quantitative analysis of twenty natural protein amino acids by GLC. Separation Sci. 2, 101-138.

Hobson R. P. (1931a) Studies on the nutrition of blowfly larvae-I. Structure and function of the alimentary tract. $F$. exp. Biol. 8, 109-123.

Hobson R. P. (1931b) On an enzyme from blowfly larvae (Lucilia sericata) which digests collagen in alkaline solution. Biochem. $\mathcal{F} .25,1458-1463$.

HofmanN E. and WÚNSCH A. (1958) Verwendung von Nitroprussidreagenz in der Papierchromatographie. Naturzuissenschaften $45,338$.

HÜBER J. (1905) Über die Koloniengrundung bei Atta sexdens. Biol. Zbl. 25, 606-619, $625-635$.

Kala H., Modenhauer H., and Wolff K. (1959) Zur Analytik einiger pharmaceutisch verwendeter Purinderivate. Pharmazie 14, 519-524.

Lesser M. A. (1938) Allantoin. Drug Cosmet. Ind. 42, 451-453, 456, 469.

Lubowe I. I. and MeccA S. B. (1959) Allantoin and aluminum derivatives in dermatological applications. Drug Cosmet. Ind. 84, 36-37, 117-118.

Marini-Bettolo G. B. and Trabacchi C. (1956) Constituents of the electric organ of Torpedo-I. Chromatographic studies. Biochim. biophys. Acta 21, 258-264.

Martin M. M., MacConnell J. G., and Gale G. R. (1969) The chemical basis for the attine ant-fungus symbiosis. Absence of antibiotics. Ann. ent. Soc. Am. 62, 386-388.

Martin M. M. and Weber N. A. (1969) The cellulose utilizing capability of the fungus cultured by the attine ant, Atta colombica tonsipes Santschi. Ann. ent. Soc. Am. In press.

Moeller A. (1893) Die Pilzgarten einiger südamerikanischen Ameisen. Bott. Mitt. Trop. 6, 1-127. 
MÜLleR F. (1874) The habits of various insects. Nature, Lond. 1874, 102-103.

PARK D. (1968) The ecology of terrestrial fungi. In The Fungi (Ed. by AINsworth G. C. and Sussmiv A. S.), 3, 5-39. Academic Press, New York.

Russell J. (1944) The colorimetric estimation of small amounts of ammonia by the phenolhypochlorite reaction. F. biol. Chem. 156, 457-461.

WATERHOUSE D. F. and IRZYKIEWICZ H. (1957) An examination of proteolytic enzymes from several insects for collaginase activity. F. Insect Physiol. 1, 18-22.

WeBER N. A. (1947) Lower Orinoco River fungus-growing ants. Boln Ent. venez. 6, 143-161.

WeBer N. A. (1956a) Fungus-growing ants and their fungi: Trachymyrmex septentrionalis. Ecology 37, 150-161.

WeBER N. A. (1956b) Fungus-growing ants and their fungi: Trachymyrmex septentrionalis seminole. Ecology 37, 197-199.

Weber N. A. (1958) Evolution in fungus-growing ants. Proc. 10th int. Congr. Ent. 2, $459-475$.

Weber N. A. (1966) Fungus-growing ants. Science, Wash. 153, 587-604.

Weber N. A. (1968) The Panamanian Atta species (Hymenoptera: Formicidae). Proc. ent. Soc. Wash. 70, 348-350.

WheEler W. M. (1907) The fungus-growing ants of North America. Bull. Am. Mus, nat. Hist. 23, 669-807. 